УДК $821.161(092)$

DOI https://doi.org/10.52726/as.humanities/2021.3.5

\title{
В. В. СФРЕМОВ
}

аспірант кафедри украӥнської та зарубіжної літератур,

Житомирський державний університет імені Івана Франка,

м. Житомир, Україна

Електронна пошта: vadym.yefermov@ukr.net

https://orcid.org/0000-0003-2708-8981

\section{РИТОРИЧНІ ТОПОСИ «СЛОВА О ПОЛКУ ІГОРЕВІМ»: ПРОМІНЬ СВІТЛА НАД ТЕМНИМИ МІСЦЯМИ ПАМ'ЯТКИ}

У статті пропонується розглянути риторичні топоси у тексті пам’ятки «Слово о полку Ігоревім», що дають можливість дослідити ідеологічні і ціннісні погляди середньовічного автора. Наслідуючи літературну традицію та канон, автор «Слова о полку Ігоревім» (далі - СПІ) не міг знехтувати правилами укладання текстів, що формувалися протягом багатьох попередніх століть, тому закономірно використовував риторичні топоси під час написання тексту пам'ятки. Як виявилося, дослідження функціонування риторичних топосів може пролити світло на декілька «темних» місць пам'ятки, зокрема на частину початкового фрагменту СПІ, що розглядається у дослідженні як типовий приклад вживання автором вступного риторичного топосу «подаю те, чого ніхто ще не чув». Класична схема панегіричного перевершення формується автором завдяки використанню оригінальної формули вживання разом епітета та порівняння. Фрагмент тексту, який прийнято вважати плачем княгині Ярославни, розглядається нами як типовий приклад використання середньовічного топосу звернення до богині природи. Риторичний топос величання руських князів формується шляхом поєднання в описі двох класичних середньовічних якостей ідеального лицаря - розуму та відваги. Риторичні топоси розглядаються як елементи непросторової організації художньої структури тексту та залежать від стадії розвитку світогляду епохи Середньовіччя, індивідуальних творчих позицій автора. Встановлено, що джерелом походження більшості риторичних топосів, використаних середньовічним автором, $\epsilon$ античні часи. Художнє вираження риторичних топосів у тексті пам'ятки СПІ розкриває складні й важливі обставини суспільно-політичного життя на території Русі у період походу князя Ігоря на половецькі землі, ідентифікує проблему принципового доленосного вибору, який виник перед князівською дружиною.

Ключові слова: риторика, топос, риторичний топос, світоглядні орієнтири, структура художнього тексту.

Постановка проблеми. У сучасному літературознавстві сформувалося два значення поняття «топос» (рис. 1).

У першому значенні ідеться про стилістичні топоси - стійкі мовні звороти, які існують незалежно від контексту літературного твору. Натомість у другому значенні топос $є$ риторичною одиницею художнього простору твору, що займає певне місце в просторовій структурі тексту. Літературознавець М. Лотман визначає риторичний топос як «просторовий континуум, в якому відображається світ об'єкта» [Лотман $1970: 280$ ]. Сформовану у художньому творі систему просторових відносин дослід- ник називає структурою топосу, яка $є$ мовою для вираження непросторових відносин у тексті [Лотман 1970 : 281]. Вчена А. Булгакова називає відмінними рисами риторичних топосів системність, залежність від стадії розвитку мистецтва, світогляду епохи, творчих позицій [Булгакова $2008: 33$ ].

Виклад основного матеріалу. ВСТУПНА ТОПІКА - ІСТОРІЯ ПОХОДУ НА «НОВИЙ» ЛАД?

Цей різновид риторичних топосів середньовічні автори використовували для того, щоб обгрунтувати визначення подальшої композиції написаного тексту. Так, одним 3 прикладів

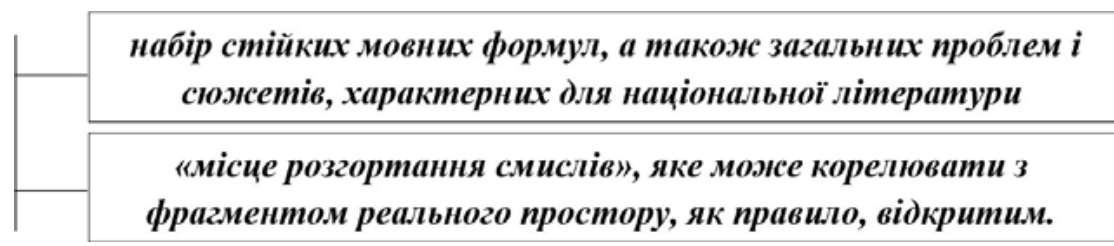

Рис. 1. Значення поняття «топос» 
реалізації такого різновиду риторичних топосів є так звана формула «подаю те, чого ніхто ще не казав», яка виникла в Стародавній Греції як відхилення «заяложеного епічного матеріалу». Ще в кінці V ст. Кирило Александрійський шукав спосіб оновлення епіки за допомогою історичного наповнення, оскільки він вважав, що стародавні перекази «пережили себе». Часто формулами виразу цього топосу були кліше на кшталт «таке ніхто ще не казав ні в римі, ані в прозі» чи «за цее не бралися щуе ні прозою, ні в римі».

$\mathrm{У}$ «СПІ» вступ починається таким словами: «Чи не гоже було б нам, браття,

\section{Розпочати давніми словами}

Скорбну повість про Ігорів похід,

Ігоря Святославовича?

А зачати нам отую пісню

По сьогоденних бувальщинах,

Не по намислу Бояновім...»

(Тут і далі текст за перекл. М. Рильського)

Історики літератури давно обгрунтували той факт, що автор «СПІ» навмисне відмовився писати, наслідуючи творчий стиль співця Бояна. Зокрема, вчений Л. Махновець, розмірковуючи над цією проблемою пам'ятки, зазначає, що Боян оспівував князів свого часу - Ярослава Мудрого, Мстислава Тьмутараканського, Романа Святославича. Він був неповторним митцем слова, відзначався силою поетичної уяви, його називали солов'єм, вважали нащадком покровителя поетів Велеса. Проте, на відміну від самого Бояна, який тільки прославляв і вихваляв князів, автор «Слова» вирішив «< .. > творити за бувальщиною свого часу, себто згідно 3 життєвою правдою. За умов, коли руське військо зазнало поразки, треба було не стільки хвалити князів, скільки докоряти їм за сваволю, незгоди, закликати до єдності, підіймати суспільну свідомість на справу оборони Русі» [Махновець 2003 : 11].

Якщо дотримуватись цієї тези, то стає зрозуміло, що автор фактично використав звичний риторичний топос, мета якого - продемонструвати читачеві, що про похід полку Ігоря говоритиметься «новими словами», яких досі не чули. На зміну «давнім словам» Бояна приходить нова авторська манера, не схожа на попередні способи опису програшу військових походів. Автор не просто констатує поразку князя, як це робилося раніше, а «хулить» Ігоря за неправильно обрану тактику ведення бою, робить акцент на незлагодженості та міжусобицях, що призвели до значних втрат людських сил в ході військового наступу, що не було притаманним манері Бояна - «давнім словам».

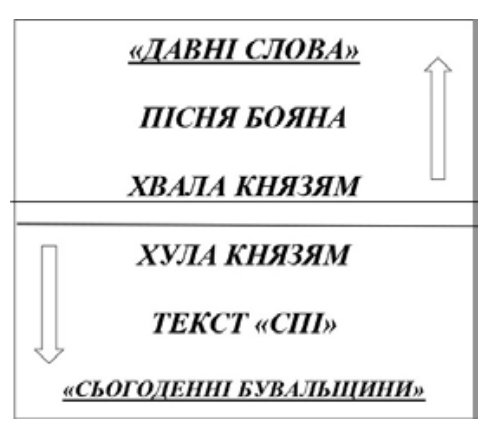

Ще одна версія прочитання заспіву «СПІ», до якої апелювали вчені В. Капніст та М. Максимович, стосувалася старого наріччя давньоруської мови, яким послуговувався Боян [Максимович 1880 : 558]. Дослідник О. Зимін висунув тезу, що для автора, який використовував мову XII ст., мова Бояна була дійсно «давньою», тому аналізований текст $\epsilon$ витвором пізнішого часу [Зимин 1967 : 143], що цілком збігається з запропонованою нами концепцією функціонування в цьому фрагменті риторичного топосу «подаю те, чого ніхто ще не казав», тобто вперше кажу «новою» мовою, промовляю «сучасними» для автора словами.

ПАНЕГІРИЧНИЙ ТОПОС ПЕРЕВЕРШЕННЯ: ДРЕВО VS БІЛКА?

Як зазначав Е. Р. Курціус, коли потрібно «похвалити» якусь особу чи річ, то всі «перебирають міру й для досягнення мети послуговуються особливою формою порівняння $<\ldots>$ на основі порівняння встановлюється перевага, навіть неповторність людини, яку славлять» [Курціус 2007 : 184]. Таку формулу він запропонував називати топосом перевершення. Функціонування цього топосу можна прослідкувати у згадці автором манери «співу Бояна»:

\section{«Розтікався мислю по дереву,}

Сірим вовком по землі,

Сизим орлом попід хмарами ...».

Тобто Боян у своїй майстерності співця відзначався значною силою та розмахом поетичної уяви, що прирівнюється автором «СПІ» до фізичних характеристик спритності та вправності представників тваринного світу - білки, вовка, орла. Якщо ідентифікувати у нечленованому тексті пам'ятки образи вовка і орла сучасним перекладачам вдається вільно, то з білкою виникає проблема. 
Досить довго у літературознавстві панує дискусія, яка поділила вчених на два табори: одні 3 них вважають, що ідеться про порівняння Бояна $з$ прудкою білкою (думки його такі ж швидкі як і рухи цієї тварини), а інші вважають, що ідеться про міфічне дерево, яке росло в царстві богів гілками вниз (А. Майков).

\begin{tabular}{|c|c|}
\hline \multicolumn{2}{|c|}{$\begin{array}{c}\text { БОЯН } \\
\text { EПITЕТ + ПОРІВНЯННЯ }\end{array}$} \\
\hline$=$ & СВІТИ \\
\hline 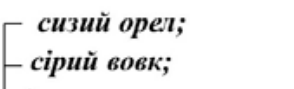 & \\
\hline дерево мисленнєве; & РОСЛИ \\
\hline
\end{tabular}

Академік М. Гудзій висунув власну тезу стосовно цього проблемного місця тексту: «Оскільки дальші дві частини цієї тричленної метафори («сьрымъ вълкомъ» і «шизымъ орломъ») містять уподібнення 3 живими істотами, то і в першій частині деякі дослідники й перекладачі замінюють «мыслію» на «мысію», тобто дерево на білку (мысію на Псковщині називали білку-летягу)» [Гудзій 1989 : 156]. Проте слово «бълль», а не «мисль» як номінація тварини зустрічається у іншому фрагменті тексту, який стосується сплати податку: «Емляху дань по бглль отъ двора». Справедливим $\epsilon$ зауваження М. Шарлеманя стосовно того, що на території України, де колись було створене «Слово<...>», ніколи не було білок-летяг, тому псковська назва тут ні до чого.

Якщо розглянути цей фрагмент у руслі топіки, то використання автором перевершення стосовно Бояна $€$ цілком закономірним, оскільки застосовується класична середньовічна схема «перевершення літератора», якому приписують значні заслуги, що відсувають в тінь найбільші твори минулого. Використовували цю схему такі античні поети, як Стацій, Авзоній, Валафрід. Панегіричний стиль дозволяв робити найсміливіші перевершення, реалізацію яких (зокрема, порівняння з кращими рисами тваринного світу) продемонстровано у «СПІ». Головною фігурою «перевершення Бояна» є поєднання порівняння та епітету: «сірим вовком», «сизим орлом», «мисленнєвим деревом». Таким чином, майстерність Бояна спочатку порівнюється з представником тваринного світу, потім світу птахів та рос- линного світу. Якщо мова первісно йшла про білку, то виникає питання стосовно того, для чого автору повторюватись у схемі панегіричного порівняння, де він вже раніше описував одного представника тваринного світу - вовка. Потрібно було використати третій, відсутній компонент возвеличення, тобто порівняння 3 рослиною. Невипадково для поета було обране древо «мисленнєве» - міфічне дерево, яке росте поряд 3 богами й уособлює Сакрум. Застосування аналізу панегіричного топосу, а також прийняття концепції возвеличення автором «СПІ» Бояна проливає світло на це «темне місце» пам'ятки на користь образу дерева, а не білки. Отже, Боян у свідомості автора не порівнюється 3 летягою, а виступає елементом триєдиного світу - тваринного, птахів та рослинного. Вважаємо правильною думку тих дослідників, які надають перевагу трактуванню цього фрагменту на користь міфічного дерева, а не «бълљъ».

\section{ЗВЕРНЕННЯ ДО ПРИРОДИ: ТОПОС VS} ПЛАЧ?

Одним 3 прикладів поетичного топосу $€$ звернення до природи. Е. Р. Курціус стверджує, що вже з античних часів цей топос отримав релігійний відтінок: «В «Іліаді» водночас 3 молитвами до богів Олімпу люди звертаються також до землі, небес, рік. У «Прометеї закутім» Есхіла герой звертається до вітрів, рік, морів, землі та сонця, щоб вони стали свідками його страждань. Герой Аякс у Софокла звертається до моря, берегів і скель, до світла, рідної землі, її джерел та потоків, але не з молитвою, а зі словами прощання» [Курціус $2007: 107]$. Німецький вчений прослідковує динаміку зміни звернення ліричних героїв до природних сил, для яких цей світ поступово «олюднювався». 3 божеств сили природи трансформуються у співчутливих істот, які допомагають поетові. Коли він прагне патетично посилити ефект від оплакування покійника, хор природи, «поділений на багато голосів, сповнює простір навколо поета своїм співом» [Курціус 2007 : 107]. Найдосконалішим в античній літературі топосом такого типу вважається оплакування Адоніса Біоном, що жив у пізню елліністичну епоху.

$\mathrm{У}$ тексті «СПІ» під час оплакування Ярославною чоловіка Ігоря, що не повернувся, читач зустрічає звернення до сил природи (рис. 2). 


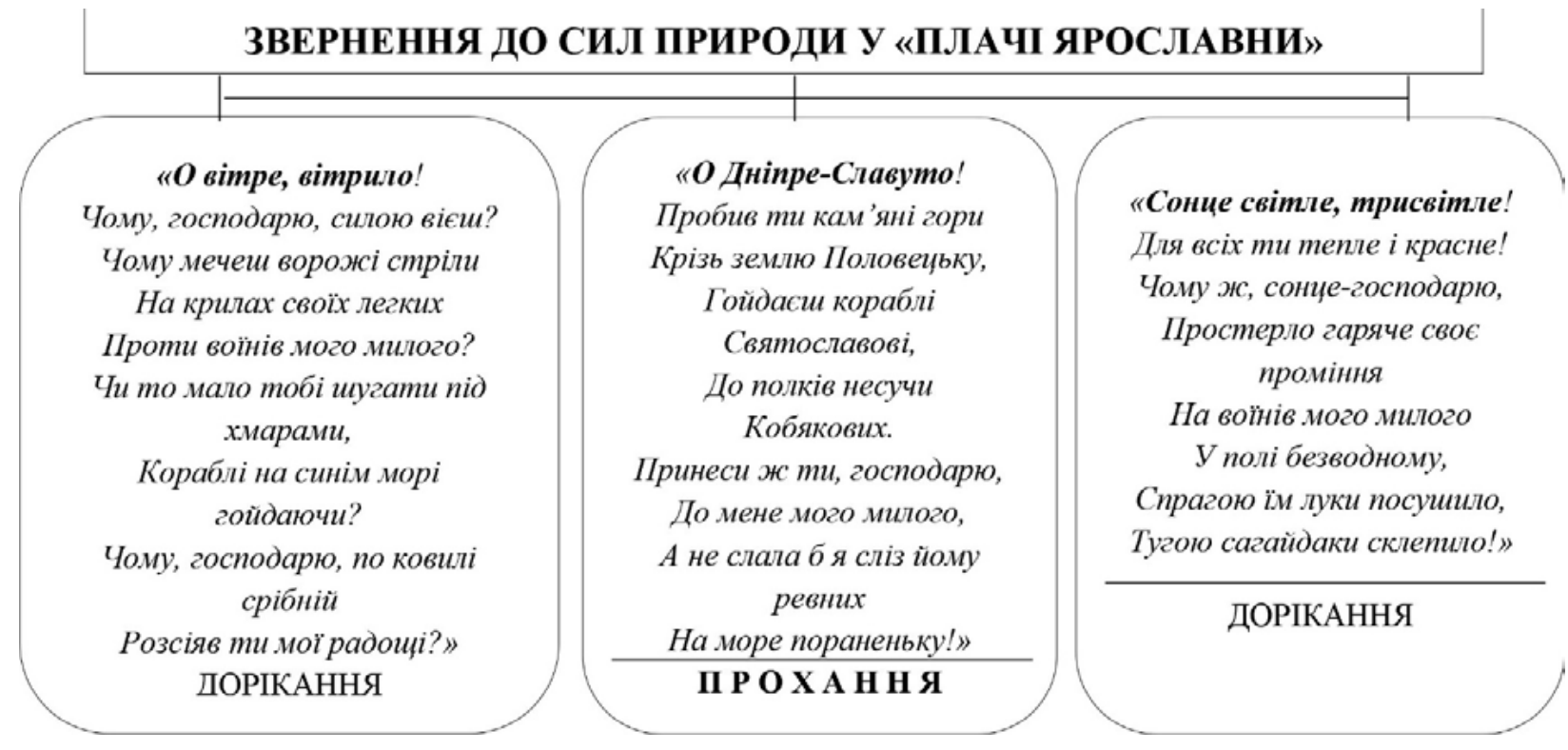

Рис. 2. Звернення до сил природи

Цей ліричний відступ у пам'ятці названо плачем. Чи насправді це так? Літературознавчий словник подає таке визначення цього терміна: «Плач - літературний жанр, а також твір, створений в цьому жанрі, - традиційні імпровізації елегійного характеру, пов'язані переважно 3 похоронами, весільними, рекрутськими й іншими обрядами, неврожаєм» [Бабенко : 653]. Тобто плач $є$ художнім втіленням скорботи за втраченою людиною або у зв'язку з будьякою трагічною подією. Екстраполюючи це визначення на фрагмент «СПІ», отримуємо твердження, що Ярославна плаче за втраченою людиною - чоловіком Ігорем - 3 приводу його смерті у битві з половцями. Тоді це визначення дисонує з іiі другим звертанням до водної стихії: «Принеси ж ти, господарю,/ До мене мого милого». Вона просить у Дніпра-Славутича, щоб той допоміг Ігорю втекти 3 полону, а не приніс на своїх водах тіло вбитого князя. Для неї як дружини, що жевріс надією на порятунок Ігоря, він ще не вмер, а є живим, тому вона і звертається з проханням про допомогу до Дніпра, а не з оплакуванням, коли традиційно виконувався плач як постфактум смерті.

Відкидає версію «плачу» і вчений П. Білоус, який вважає, що він «насправді за формою, змістом, міфологічними образами нагадує язичницьке замовляння. Тут Ігоря названо «ладо» (Ладо у давньоукраїнській міфології - бог кохання, шлюбу і родинної злагоди)» [Білоус $2015: 26]$.
Чим же насправді $є$ ця частина пам'ятки? Проаналізувавши риторичні топоси тексту «СПІ», можемо дійти висновку, що це не що інше, як згаданий нами клішований приклад поетичного топосу звернення до природи, який використав автор для підсилення ефекту страждань Ярославни. Середньовічний автор сміливо звертався вустами княгині до природних сил, оскільки він добре знав, що природа створена Богом. Отже, творіння Боже повинно змилуватись над благанням про поміч християнському князю, якого намагаються вбити нехрещені половці. Прослідковується опозиція двох світів - православної Русі та нехрещеного Поля, а також християнського князя та половецького хана. Православна Ярославна закликає весь світ і сили природи допомогти Ігорю повернутися живим, а не виголошує плач.

ВЕЛИЧАННЯ ПРАВИТЕЛІВ: «УМ НА ДЕЛО»VS «УМНЕ ДЕЛО॥

Витоки цього топосу сягають античного культу героїв. Герой виступає для античних поетів ідеальним типом особистості, чий

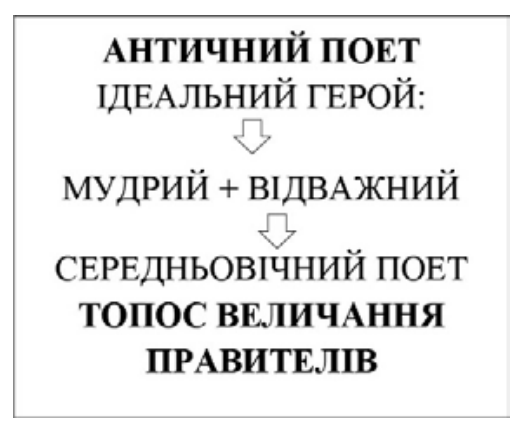


«стрижень буття спрямований на шляхетне, отже, на «чисті», нетехнічні життєві вартості, а його головна чеснота - природна шляхетність тіла і душі» [Курціус 2007 : 190]. Ідеальним постає поєднання відваги та мудрості, оскільки мудра порада потрібна так само, як і відважний подвиг. Мудрість від досвіду приходить лише з роками, а молодості бракує розуміння. Навіть від звичайного воїна вимагається знання воєнного ремесла та наявності бойового гарту, що передбачає наявність як мудрості, так і відваги. Натомість князі мають поєднувати відвагу та мудрість на найвищому рівні.

Трансформацією топосу героя став топос величання правителів, де місце мудрості змінює освіченість. Архаїчна полярність «мудрість - відважність» у процесі культурного переродження перетворюється на новий диференційований образ. Коли автор «СПІ» промовляє словами Святослава до князів Романа та Мстислава закликом:

«А ти, буй-Романе, і ти, Мстиславе!

Мисль одважна

Покликає ваш розум на діло»,

він возвеличує МУДРИЙ намір обох князів помститися за пролиту кров Ігоря. Багато дослідників перекладає цей фрагмент в цьому ж руслі, варіюється лише остання фраза, синонімічно змінюючись: «розум на діло/ подвиг/ подвиг високий/ битву».

Першим, кого зацікавив цей фрагмент, став дослідник В. Скляренко, який поставив під сумнів те, як думка (навіть хоробра) може нести (вести) розум на діло. I на яке діло? На його думку, аналізована фраза явно знижує стиль поеми, через що велика група дослідників змушена була слово дъло перекладати як «подвиг». Через свої сумніви дослідник вважав, що аналізовану фразу перші видавці «Слова $<\ldots .>$ » і всі подальші дослідники зрозуміли неправильно: «Автор «Слова <..>» цією фразою хотів сказати, що в Романа і Мстислава поєднуються хоробрість і розум, що хоробрість не затьмарює їм обом розум, що хоробрість подвигає їх обох лише на розумні вчинки. Тобто не треба виправляти «васъ» на «ваю» чи «вашъ(ь)». Треба лише «умь_на» читати разом як «умьно (дъло)» [Скляренко 2010 : 34].

$\mathcal{E}$ всі підстави підтримати саме таке прочитання цього фрагменту, оскільки автор «Слова $<\ldots>$ » тут, очевидно, вжив риторичний топос величання правителя, який повинен був традиційно містити у собі під час характеристики князів два обов'язкових елементи - розум (ум) та звитягу (дьло - військову битву) (рис. 3).

Якщо досліджувати цей фрагмент як риторичний топос, то не виникатиме жодних питань стосовно того, яким чином думка може закликати розум до діла. Автор наголошує, що лише розумна тактика ведення наступальної операції руських князів, коли вони об'єднають всі свої сили, призведе до «розумної» битви, тобто князі мають спиратись не лише на свої військову звитягу та запал. Цей шлях вбачається як єдиний переможний перед загрозою повторних нападів з боку половців, що отримали моральне піднесення після розгрому війська князя Ігоря.

Хоча князя Ігоря автор теж возвеличує, застосовуючи подібну схему ще на початку заспіву:

«Ігор сей, славен князь,

\section{Міццю розум оперезав,}

Мужністю сердечною нагострив»,

наперед знаючи, що він програє похід та «відкриє» ворота Русі для половців. Це цілком пояснюється в контексті ідеї написання «СПІ»реабілітації князя, про що зазначає П. Білоус: «Автор 3 помітною симпатією ставиться до князя, вболіває за нього, наділяє рисами лицарської звитяги і честі. За що така повага? Князь затіяв авантюрний похід, зазнав невдачі, принизив гідність руського війська в очах половців. Виходить, автор намагався реабілітувати Ігоря в очах сучасників, а це наводить на думку, що він був приятелем князя чи особою, наближеною до нього» [Білоус 2015 : 27].

Як аргумент на підтвердження тези реабілітації Ігоря звучить використання автором ще одного риторичного топоса - «весь світ оспівує його». Цю схему часто використовували каролінгські поети, возвеличуючи фігуру Карла

\begin{tabular}{|l|l|l|l}
\hline КНЯЗІ РОМАН & \multicolumn{1}{|l}{ ВЕЛИЧАННЯ «УМНЕ ДЕЛО»= } \\
МСТИСЛАВ ФОРМУЛА & ПРАВИТЕЛЯ РОЗУМНА БИТВА
\end{tabular}

Pис. 3 
Великого. Ця схема була поширена в давньогерманській героїчній творчості (возвеличувала готського героя Генсимунда). Схожу схему знаходимо і в останній частині пам'ятки:

"Сонце сяє в небі ясному,

Ігор-князь - у Руській землі!

Дівчата співають на Дунаї,

В'ються голоси через море

До Києва-города».

Висновки. Автор на початку твору символічно повідомляє, що «тяжко Руській землі без Ігоря» під час його перебування в полоні, а коли князь повертається до рідної землі, то стає свідком власного «оспівування». До того ж возвеличують Ігоря не тільки його піддані від Дунаю, що був найвіддаленішим куточком, де проживали русичі, до центру - Дніпра, а навіть природа радіє поверненню народного героя («сонце сяє в небі!») 3 поверненням володаря радість повертається на Руські землі, відбувається ії персоніфіковане переродження: «Землі раді, городи веселі».

\section{ЛІТЕРАТУРА}

1. Білоус П. В. Для чого було створене «Слово про Ігорів похід». Житомирські літературознавчі студії. 2015. № 8. C. 20-32.

2. Булгакова А. Топика в литературном процессе. Гродно, 2008. 107 с.

3. Гудзий Н. К. Литература Киевской Руси и украинско-русское литературное единение. Киев, 1989. С. 153-180.

4. Зимин А. Когда было написано «Слово»? Вопросы литературы. 1967. № 3. С. 143.

5. Курціус Е. Р. Європейська література і латинське середньовіччя / перекл. 3 нім. А. Онишко. Львів : Літопис, 2007. $752 \mathrm{c}$.

6. Лихачёв Д. Литературный этикет Древней Руси. Труды Отдела древнерусской литературы. Москва. 1961. Т. 17. $699 \mathrm{c}$.

7. Лотман Ю. Структура художественного текста. Москва : Искусство, 1970. 192 с.

8. Максимович М. А. Собрание сочинений. Киев, 1880.558 с.

9. Махновець Л., Мишанич О. «Слово о полку Ігоревім» та його поетичні переклади й переспіви в українській літературі. Київ, 2003. 110 с.

10. Рильський М. Слово про Ігорів похід. Київ : Артикул, 2015. 183 с.

11. Скляренко В. Г. «Темні місця» в «Слові о полку Ігоревім». Мовознавство. 2010. № 2-3. С. 30-40.

12. Словарь синонимов русского языка / под общ. ред. Л. Г. Бабенко. Москва : АСТ, Астрель, 2011. 688 с.

\section{REFERENCES}

1. Bilous P. V. (2015) For what it was created "The word about Igor Hiking" [For what it was created "The word about Igor Hiking"]. Zhytomyr literary studios, no. 8, pp. 20-32.

2. Bulgakova A. (2008) Topik in the literary process [Topik in the literary process]. Grodno. (in Belarus)

3. Gudzia. N. K. (1989) Literature of Kiev Rus and Ukrainian Literary Edinenie [Literature of Kiev Rus and Ukrainian Literary Edinenie]. Kyiv. (in Ukrainian)

4. Zimin A. (1967) Kohda Boylo wrote "Word"? [Kohda Boylo wrote "Word"?] Literature tests, no. 3, p. 143.

5. Kurceus E. R. (2007) European literature and Latin / translated with it. A. Onyshko. [ European literature and Latin / translated with it. A. Onyshko]. Lviv : Chronicle. (in Ukrainian)

6. Likhačev D.S. (1961) Literary Etiquette of the Ancient Rus (to the problem of discontinuation) [Literary Etiquette of the Ancient Rus (to the problem of discontinuation)]. Deals Dedekhova Literature, no. 17, p. 699.

7. Lotman Yu. (1880) Structure of artistic texts [Structure of artistic texts]. Moscow : Art. (in Russian)

8. Maximovich M. A. (1880) Subscribe [Subscribe]. Kyiv. (in Ukrainian)

9. Makhnets L., Mishanich O. ( 2015) Word of the Regiment Igorev and his poetic translations and reversions in Ukrainian literature [Word of the Regiment Igorev and his poetic translations and reversions in Ukrainian literature]. Acta. (in Ukrainian)

10. Rylskyi M. (2015) A word about Igor's campaign [A word about Igor's campaign]. Kyiv : Article. (in Ukrainian)

11. Sklyarenko V. G. (2010) "Dark places" in the "Word of the Igor Regiment" ["Dark places" in the "Word of the Igor Regiment"]. Linguistics, no. 2-3, pp.30-40.

12. Babenko. L. G. (2011) Slovar synonym of Russian language / prof. L. G. Babenko [Slovar synonym of Russian language / prof. L. G. Babenko]. Lingua, AST, Astrel. (in Russian) 


\section{V. YEFREMOV}

Postgraduate Student at the Departments of Ukrainian and Foreign Literature, Zhytomyr State University Ivan Franko, Zhytomyr, Ukraine

E-mail:Vadym.Yefermov@ukr.net

https://orcid.org/0000-0003-2708-8981

\section{RHETORICAL TPOS THE “TALE OF IGOR'S CAMPAIGN": BEAM OF LIGHT OVER DARK PLACE OF MONUMENT}

The article proposes to consider rhetorical topos in the text of the memoir "A Tale of Igor's Regiment", which provide an opportunity to explore the ideological and value views of the medieval author. Following the literary tradition and canon, the author of "Slova o polku Igorevim" (SPI) could not ignore the rules of composing texts that were formed over many previous centuries, so he naturally used rhetorical topos when writing his own text of the monument. The study of the functioning of rhetorical topos turned out to "shed" light on several "dark" places of the monument, in particular: part of the initial fragment of the SPI, which is considered in the study as a typical example of the author's use of introductory rhetorical topos; the classical scheme of panegyric superiority is formed by the author through the use of the original formula of using the epithet and comparison together; a fragment of the text, which is considered to be the "cry" of Princess Yaroslavna, is considered by us instead as a typical example of the use of a medieval topos address to the Goddess of Nature; the rhetorical topos of the glorification of Russian princes is formed by combining in the description of two classical medieval qualities of the ideal knight: reason and courage. Rhetorical topos are considered as elements of non-spatial organization of the artistic structure of the text and depend on the stage of development of the worldview of the Middle Ages, the individual creative positions of the author. It is established that the source of most of the rhetorical topos used by the medieval author is ancient times. The artistic expression of rhetorical topos in the text of the SPI monument reveals the complex and important circumstances of socio-political life in Russia during the campaign of Prince Igor in the Polovtsian lands, identifies the problem of fundamental fateful choice that arose before the prince's wife.

Key words: rhetoric, topos, a rhetorical topos, swegan guidelines, structure of the artistic text. 